\title{
8
}
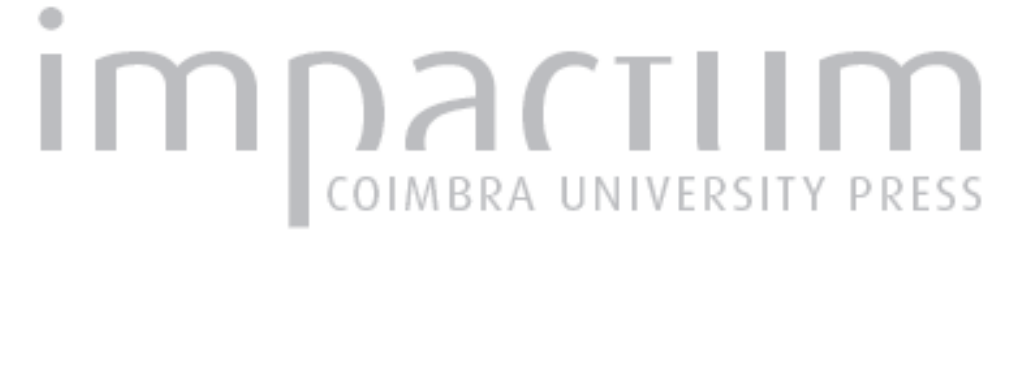

\section{Religião, religiões e diálogo inter-religioso}

\section{Autor(es): $\quad$ Borges, Anselmo}

Publicado por: Instituto de História Económica e Social, Faculdade de Letras

URL persistente:

URI:http://hdl.handle.net/10316.2/11961

DOI:

DOI:http://dx.doi.org/10.14195/0870-4147_40_1

Accessed : $\quad$ 26-Apr-2023 01:08:05

A navegação consulta e descarregamento dos títulos inseridos nas Bibliotecas Digitais UC Digitalis, UC Pombalina e UC Impactum, pressupõem a aceitação plena e sem reservas dos Termos e Condições de Uso destas Bibliotecas Digitais, disponíveis em https://digitalis.uc.pt/pt-pt/termos.

Conforme exposto nos referidos Termos e Condições de Uso, o descarregamento de títulos de acesso restrito requer uma licença válida de autorização devendo o utilizador aceder ao(s) documento(s) a partir de um endereço de IP da instituição detentora da supramencionada licença.

Ao utilizador é apenas permitido o descarregamento para uso pessoal, pelo que o emprego do(s) título(s) descarregado(s) para outro fim, designadamente comercial, carece de autorização do respetivo autor ou editor da obra.

Na medida em que todas as obras da UC Digitalis se encontram protegidas pelo Código do Direito de Autor e Direitos Conexos e demais legislação aplicável, toda a cópia, parcial ou total, deste documento, nos casos em que é legalmente admitida, deverá conter ou fazer-se acompanhar por este aviso.

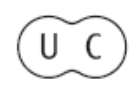



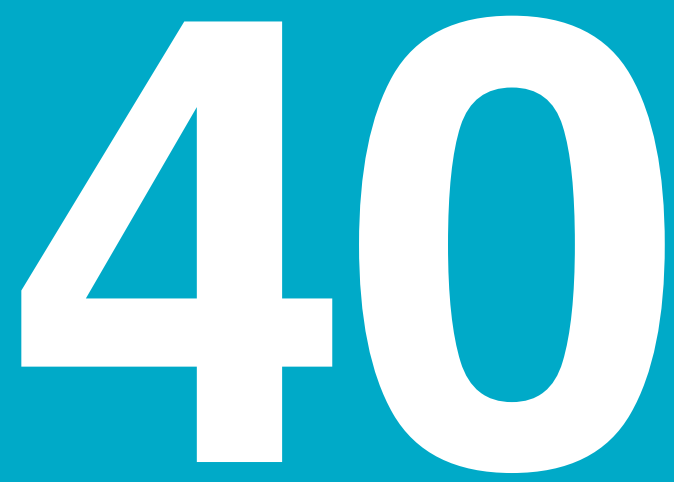

\section{Revista Portuguesa de História}

Faculdade de Letras da Universidade de Coimbra Instituto de História Económica e Social

Coimbra 08/09 
Revista Portuguesa de História

t. XL (2008/2009)

pp. $9-44$

\section{Religião, religiões \\ e diálogo inter-religioso}

ANSElmo Borges

Universidade de Coimbra

Esta introdução à problemática da religião/religiões tem dois objectivos fundamentais: em primeiro lugar, tentar uma "definiçãa" de religião (I) e, depois, estabelecer o quadro essencial das condições de possibilidade do necessário e urgente diálogo inter-religioso (II).

\section{I}

1. A Encyclopedia Britannica apresentou, em 2006, a distribuição e percentagem das "religiões universais". Cristãos: 2.133.806.000 $(33,1 \%)$, sendo os católicos 1.118.991.000 (17,3\%), os protestantes $375.815 .000(5,8 \%)$, os ortodoxos $219.501 .000(3,4 \%)$, os anglicanos 79.718 .000 (1,2\%), outros cristãos $459.321 .000(7,1 \%)$, cristãos sem filiação 113.622 .000 (1,8\%). Muçulmanos: 1.308.941.000 (20,3\%). Hindus: 860.133 .000 (13,3\%). Budistas: 378.808 .000 $(5,9 \%)$.

Aparecem também os outros grupos. Não religiosos: 769.379 .000 (11,9\%). Religiões populares chinesas: 404.921 .900 (6,3\%). Religiões étnicas: 256.332.000 (4,0\%). Ateus: 151.612 .000 (2,3\%). Novas religiões: 108.131.200 $(1,7 \%)$. 
Embora as estatísticas no domínio religioso tenham de ser vistas com os seus limites próprios - basta pensar em quantos se afirmam cristãos, mas não praticantes -, estes números são, pelo menos, indicativos, concluindo-se que, se a população do planeta estava calculada em meados de 2005 em 6.453.628.000, só cristãos, muçulmanos, hindus e budistas totalizavam praticamente $73 \%{ }^{1}$.

Mas o que é a religião? O que deve entender-se por pessoa religiosa? Onde se fundamenta a religião? Qual é o dinamismo que está na base das religiões?

Toda a religião tem a ver com a ética e também com a estética. Hegel viu bem quando afirmou que a arte, a religião e a filosofia estão referidas ao Absoluto. A pergunta é, como escreve o filósofo José Gómez Caffarena, se a ética, a estética e a filosofia acabarão por absorver a religião, como já insinuava Goethe: "quem tem arte (e moral e filosofia) tem religião; quem a não tem que tenha religião" 2 .

Segundo Lucrécio, "o medo criou os deuses"3. Desde então, isso tem sido repetido, acrescentando a ignorância e a impotência, de tal modo que, com a avanço da ciência e da técnica, a religião acabaria por ser superada e desaparecer.

Será, porém, verdade que na génese da religião estão o medo, a ignorância e a impotência? Ninguém poderá negá-lo. A questão é saber se esses são os únicos e decisivos factores e de que modo actuam. De facto, não é a limitação enquanto tal que está na base da religião, mas a consciência da limitação. $\mathrm{Na}$ consciência da finitude, que tem a sua máxima expressão na consciência da mortalidade, o Homem transcende o limite e articula um mundo simbólico de esperança de sentido último e salvação. Como disse Hegel, a verdade do finito encontra-se no Infinito, e Kant viu bem, ao referir a religião à esperança de um sentido final ${ }^{4}$.

Assim, é possível que a ciência e a técnica obscureçam a força do apelo religioso. Mas, permanecendo a finitude e a sua consciência, há-de erguer-se sempre a pergunta pelo sentido último. Como disse Ciorán, "tudo se pode sufocar no Homem, salvo a necessidade do Absoluto, que sobreviverá à destruição dos templos e mesmo ao desaparecimento da religião". Na mesma

1 Cf. José Gómez Caffarena, El Enigma y el Misterio. Una filosofía de la religión, Madrid, 2007, pp. 87-88.

2 Cit. in: Id., o.c., p. 84.

3 De rerum natura, vv. 1161-1193.

4 Immanuel Kant, Logik, in: Id., Werkausgabe. Band VI, Frankfurt/., 1991, 8. . ed., pp. 447-448: O campo da filosofia pode reduzir-se às seguintes perguntas: "O que posso saber? O que devo fazer? O que me é permitido esperar? O que é o homem? À primeira pergunta responde a metafísica, à segunda a moral, à terceira a religião e à quarta a antropologia". 
linha de pensamento, afirma L. Rougier: "A Igreja pode declinar: o sentimento religioso grávido de um impulso para o ideal, de uma sede do absoluto, de uma necessidade de superar-se, que os teólogos chamam transcendência, subsistirá." ${ }^{5}$

O que, do ponto de vista biológico, une a Humanidade é a interfecundidade. Do ponto de vista espiritual, o que a une é a pergunta radical pela totalidade e o seu sentido. O Homem é o animal que pergunta pelo seu ser e pelo ser.

A razão humana não cria a partir do nada. Ela constrói a partir do dado e, feito todo o seu percurso, sabe que acende a sua luz na noite do Mistério. Se pergunta, é porque ela própria é perguntada pela realidade, que é ambígua. Precisamente na sua ambiguidade, provocando, por isso, espanto positivo e negativo, a realidade e a existência convocam para a pergunta radical: o que é o Ser?, o que é o Homem?

Quando, na evolução, se deu a passagem do animal ao Homem, apareceu no mundo uma forma de vida inquieta que leva consigo constitutivamente a pergunta pelo sentido de todos os sentidos, portanto, a pergunta pelo sentido último. A dinâmica religiosa deriva da experiência de contingência radical e da esperança num sentido final. A mesma experiência tem um duplo pólo: a radical problematicidade do mundo e da existência e a referência em esperança a uma resposta de sentido último, plenitude, felicidade, orientação, identidade, salvação.

Este domínio da busca de sentido aparece de modo tão central na vida humana que a história da Humanidade não se compreende sem a história da consciência religiosa, não sendo de esperar o fim da religião e das religiões.

Neste contexto, não é ousado afirmar que todo o ser humano é religioso, na medida em que é confrontado com a pergunta pela ultimidade. Só poderíamos falar de irreligiosidade no caso de alguém se contentar com a imediatidade empírica, recusando todo e qualquer movimento de transcendimento.

O Homem tem uma constituição paradoxal. Por vezes, constata que fez aquilo de que se espanta negativamente, erguendo, perplexo, a pergunta: como foi possível ter feito isso? - aí, não era eu. Há, pois, o "isso" em nós sem nós, de tal modo que fazemos a experiência do infra ou extra-pessoal em nós. Talvez fosse a isso que São Paulo se referia quando escreveu: "Que homem miserável sou eu! É que não é o bem que eu quero que faço, mas o mal que eu não quero, isso é que pratico" 6 .

\footnotetext{
5 Cit. in: Jesus Avelino de la Pienda, El problema de la religión, Madrid, 1998, p. 99.

${ }^{6}$ Rm. 7, 24. 19.
} 
Por outro lado, o Homem dá consigo como sendo mais do que o que é: ainda não é o que quer e há-de ser. Ainda não sou o que serei. Uma das raízes da pergunta pelo Homem deriva precisamente desta experiência: eu sou eu, portanto, idêntico a mim, mas não completamente idêntico, porque ainda não sou totalmente eu. Então, o que sou?, o que somos?, o que é o Homem?

O Homem não se contenta com o dado. Quer mais, ser mais, numa abertura sem fim. Exprimindo esta abertura ilimitada, há uma série de expressões famosas: citius, altius, fortius (mais rápido, mais alto, mais forte), o lema olímpico; o Homem é bestia cupidissima rerum novarum (animal ansiosíssimo por coisas novas), dizia Santo Agostinho; Max Scheler definiu-o como "o eterno Fausto" e Nietzsche como "o único animal que pode prometer"; Unamuno escreveu: "mais, mais e cada vez mais; quero ser eu e, sem deixar de sê-lo, ser também os outros." Mesmo na morte, o Homem não está acabado, pois é o animal do transcendimento e sempre inconcluído. Precisamente a inconclusão mostra que a sua temporalidade e o seu ser têm uma estrutura essencialmente aberta.

O Homem não pode não transcender, mesmo se, como escreveu o teólogo Leonardo Boff, há o bom e o mau transcender. Exemplos do mau transcender e má transcendência são a droga, o álcool em excesso, a religião enquanto superstição alienante. A vida é exaltante, mas também é terrível por vezes traz exigências, dificuldades, opções que exigem algo de heróico. E há quem não aguenta. E foge-se, alienado, para a droga, por exemplo, e "viaja-se". Mas, quando se regressa da "viagem", os problemas estão lá todos, com uma agravante: há menos força para enfrentá-los e superá-los, na alegria de crescer e transcender. No bom transcender - no amor, na produção, na investigação, na obra de arte, na contemplação da beleza, na generosidade frente à vida, na religião criadora -, o horizonte alarga-se, há mais vida partilhada, humanidade livre, justa e feliz, criação do novo, esperança que toca o Além ${ }^{7}$.

Permanece, portanto, a pergunta ineludível: qual é o termo da força do transcendimento humano? Por outra palavras: qual é o sentido último da existência ${ }^{8}$

7 Leonardo Boff, Tempo de transcendência, Rio de Janeiro, 2000.

8 No limite, o autêntico ateísmo coerente seria "o ateísmo silencioso", como escreve Georges Minois, aquele que não pusesse sequer a questão de Deus. Pergunta-se, porém, se precisamente a questão de Deus enquanto questão, independentemente da resposta positiva ou negativa que se lhe dê, e a questão do sentido último, não são constitutivas do ser humano. Citando Georges Gusdorf, G. Minois conclui a sua Histoire de l'athéisme, Paris, 1998, pp. 587-588, "com um quadro implacável e lúcido" da Humanidade do ano 2000: "vive no Grande Interregno dos valores, condenada a uma travessia do deserto axiológico de que ninguém pode prever o fim”. Durante muito tempo perseguido, o ateu obteve o direito de cidadania no século XIX e acreditou mesmo 
Compreendida num sentido amplo, a religião é constitutiva do ser humano. Segundo Raimon Panikkar, um estudo intercultural da realidade descobre o seguinte: a) há em toda a cultura algo que tem a ver com a consciência que o homem dessa cultura tem de si mesmo. Poderíamos denominar isso $x$, que é o enigma do homem na sua situação no mundo; b) existe também um ideal, termo ou fim da existência humana que poderíamos denominar $y$, que é o que o homem pensa que deve ser e que será; c) há, por outro lado, a convicção de que $x$ é diferente de $y$ e que há um caminho e relação entre os dois. Precisamente este último ponto poderia exprimir-se dizendo que $y$ é função de $x$ : $\mathrm{f}(\mathrm{x})=\mathrm{y}$, sendo esta função o que se chama religião, portanto, o caminho que leva de $x$ a $y$.

Assim, religião é "o que os homens crêem que exerce esta função, isto é, o que crêem que os levará de $\mathrm{x}$, a sua condição humana como a vêem, a y, a finalidade ou o fim da sua própria existência, chame-se-lhe libertação, salvação, sociedade perfeita, justiça, céu ou com outras palavras como soteria, moksha, nirvana, etc." Por paradoxal que pareça, a própria posição niilista bem como a posição monista extrema não estão fora desta definição, desde que se considere que a única condição necessária para a realidade desta função é que "x seja diferente de y". Ora, "é esse o caso, mesmo quando se diz que y 'é' o nada ou que x já é em última instância idêntico a y”. De facto, enquanto eu não "souber" que x é igual a y, não realizei essa identidade. Os homens dedicamse às religiões precisamente porque acreditam que elas realizam esta função: "dar o máximo sentido possível à vida humana."

Neste quadro, pode dizer-se que a religião é "um transcendental humano" e um existencial inerente ao ser humano enquanto tal. A religião, neste sentido, pode definir-se como "a dimensão de ultimidade do homem. As diferentes formas de entender e interpretar esta dimensão é que constituem as diferentes religiões no seu sentido antropológico e as cristalizações históricas das mesmas, a religião no seu sentido sociológico." 9

poder proclamar a morte de Deus. Mas já no fim do século XX houve a tomada de consciência de que, "ao eclipsar-se, Deus levou consigo o sentido do mundo". E continua: o futuro é imprevisível, porque o ateísmo e a fé enquanto compreensão global do mundo andaram sempre juntos. A ideia de Deus era um modo de apreender o universo na sua totalidade e dar-lhe, de forma teísta ou ateia, um sentido. Assim, a divisão hoje já não está tanto entre crentes e descrentes como entre "aqueles que afirmam a possibilidade de pensar globalmente o mundo, de modo divino ou ateu, e os que se limitam a uma visão fragmentária em que predomina o aqui e agora, o imediato localizado. Se esta segunda atitude prevalecer, isso significa que a Humanidade abdica da sua procura de sentido."

9 Raimon Panikkar, “'La religión del futuro”, in: Manuel Fraijó (Ed.), Filosofía de la religión. Estudios y textos, Madrid, 1994, pp. 745-747. 
2. Em ordem a uma tentativa de definição mais precisa, também pode ajudar um percurso pela etimologia.

Antes do cristianismo, encontramos dois étimos. Um refere religio e religiosus a religere, no sentido do cumprimento dos deveres de culto. O documento mais antigo seria um verso que Nigidius Figulus (100-45 a. C.) tomou de um cântico para confirmar a etimologia de "religiosus" e que o escritor romano Aulus Gellius (130-170) cita: "religentem esse opportet, religiosus ne fias" (Noctes Atticae IV, 9, 1), com o significado de que se deve ser consciencioso, escrupuloso, para se não ser "supersticioso"10.

Nigidius Figulus era amigo de Cícero (106-43), que, num texto célebre, apresenta relegere como étimo: "As pessoas que passam o dia inteiro a rezar e oferecendo sacrifícios para assegurar que os seus filhos lhes sobrevivam - de superstes, sobrevivente - são chamadas 'supersticiosas'. Por outro lado, os que revêem cuidadosamente e por assim dizer 'relêem' (relegerent) todo o saber ritual são chamados religiosos (dicti religiosi)" (De natura deorum II, 72) ${ }^{11}$. Trata-se, portanto, de superar a superstição, mediante uma atenção cuidadosa, uma consideração conscienciosa, uma releitura (legere: ler) constante.

Se, na religião romana, o acento caía na dimensão cultual, com o cristianismo, sublinha-se a ligação com o Deus pessoal. É sintomático que Lactâncio faça derivar religião de religari, rejeitando explicitamente a etimologia de Cícero: "Mediante este vínculo da piedade estamos comprometidos e ligados (religati) a Deus" (Divinae Institutiones IV, 28, 2). Santo Agostinho, que conhecia as etimologias pré-cristãs, adere à de Lactâncio, pois trata-se de "ligar as nossas almas com Deus" ("religantes animas nostras") (Retractationes I, 12, 9), vendo, no entanto, outra possibilidade, derivando-a de reeligere, voltar a escolher, reeleger (Retractationes 1,13 ). De qualquer forma, continua a discutir-se ainda hoje a verdadeira etimologia, apresentando inclusivamente outras hipóteses, ao mesmo tempo que se chama a atenção para o facto de que religio e religiosus não são termos técnicos da mais antiga 'religião' romana - os primeiros documentos encontram-se nas comédias de Plauto (250-184 a. C.) e na linguagem política de Catão (234-149) -, sendo usados ao longo da Idade Média sobretudo para significar as Ordens religiosas e os seus membros, como acontece ainda hoje no Código de Direito Canónico da Igreja Católica ${ }^{12}$.

${ }^{10}$ Johann Figl (Hrsg.), Religionswissenschaft. Religionen und ihre zentralen Themen, Innsbruck, 2003, p. 63.

${ }^{11}$ Jesus Avelino de la Pienda, o. c., p. 23.

${ }^{12}$ Para todas estas citações, ver J. Figl, o. c., pp. 63-64. 
$\mathrm{Na}$ época romana, para lá de religio, encontramos outros termos, como caeremonia, cultus, ritus, sacra, mas será religio que acabará por impor-se para designar o fenómeno religioso no seu conjunto, ao qual pertencem a relação subjectiva, as representações, as práticas cultuais e as instituições que as regulam. A palavra religião foi utilizada ao longo da história do pensamento cristão com múltiplos sentidos: para significar o cristianismo, religião cristã; a relação do Homem com Deus e a virtude que lhe permite prestar o culto devido a Deus; alguma instituição concreta: "entrar em religião". Na época moderna, a palavra - praticamente todas as línguas europeias têm esse conceito a partir do latim - começou a ser utilizada pelas ciências das religiões no plural para designar aquele conjunto de factos humanos, presentes em toda a história da Humanidade, diferentes segundo a história e as culturas, mas dotados de "suficientes traços comuns" para receberem o nome com que se designou o cristianismo ${ }^{13}$.

Na tentativa de definir a religião, alguns propõem definições substantivas e outros, definições funcionais. Dada a sua complexidade, indicaremos aqui, em primeiro lugar, as múltiplas dimensões do fenómeno religioso, começando, portanto, por aqueles que preferem as definições ditas multidimensionais.

Segundo Émile Durkheim, os fenómenos religiosos poderiam dividir-se de modo natural em "duas categorias: as convicções de fé e os ritos", estando as duas em conexão com a ideia de comunidade. Assim, dever-se-á considerar três características ou aspectos da religião: as convicções de fé (mitos), as práticas rituais e a comunidade congregada pela confissão da mesma fé e pela prática dos mesmos ritos.

Joachim Wach distingue igualmente três domínios nos quais se exprime a experiência religiosa: teorético - domínio do pensamento -, prático - domínio da acção, - e social - domínio da comunidade. Também Frederick Spreng distingue três dimensões primárias na religião: a dimensão pessoal, a dimensão cultual-cultural e a de ultimidade - referência ao Último.

Com Rodney Stark, Charles Y. Glock distingue cinco dimensões, que, segundo o seu modelo, se encontram presentes em todas as religiões: a ideológica, referente às afirmações de fé; a ritual; a experiencial, referente à vivência religiosa pessoal; a intelectual, relativa à reflexão sobre os conteúdos doutrinais; finalmente, a praxística, referente às consequências práticas da fé na vida concreta, individual e social. Em conexão com Glock, Ursula Boos-Nünning acrescentou uma sexta dimensão: a ligação à comunidade paroquial.

${ }^{13}$ Juan Martín Velasco, "Religião", in: Mariano Moreno Villa (Dir.), Dicionário de pensamento contemporâneo, São Paulo, 2000, p. 650. 
Ninian Smart começou por apresentar seis dimensões, mas acabou por distinguir sete: a prática e ritual; a experiencial e emocional; a narrativa ou mítica; a doutrinal e filosófica; a ética e jurídica; a social e institucional; a material, incluindo aqui, por exemplo, a arte e os edifícios.

Resumindo e concluindo, é necessário reconhecer, nas diferentes religiões, pelo menos quatro dimensões essenciais: uma dimensão intelectual-emocional, onde se incluem crenças, doutrinas, a reflexão; uma dimensão ritual-celebrativa; uma dimensão praxística, com os aspectos morais, caritativos, de combate pela justiça; uma dimensão comunitária, já que as anteriores dimensões são vividas comunitariamente e estabelecem laços de comunidade. Em síntese: uma dimensão intelectual, uma dimensão ritual, uma dimensão ético-moral.

Não sem razão, Ninian Smart pensa que as sete dimensões se encontram nas religiões mais significativas, acrescentando que este modelo das sete dimensões é aplicável inclusivamente, de forma mais ou menos estrita, a sistema seculares, como o marxismo, o nacionalismo, etc., mesmo se se não trata de religiões em sentido próprio ${ }^{14}$.

Faz-se deste modo a ponte para as chamadas definições funcionais de religião, com Émile Durkheim à cabeça, com a sua definição clássica na obra As formas elementares da vida religiosa: "Uma religião é um sistema solidário de convicções e práticas que se referem a coisas, convicções e práticas sagradas, isto é, separadas e proibidas, que unem todos os seus membros numa e mesma comunidade moral, chamada Igreja." Neste tipo de definição, sublinha-se, portanto, a função social da religião, que é mesmo definida a partir da sua função. De facto, segundo Durkheim, a religião é "essencialmente uma questão colectiva" 15 .

Sociólogos como Th. Luckmann e Peter L. Berger caminham por esta via de compreensão da religião. Assim, Luckman escreve: "A religião não é uma grandeza constante, determinada pelo conteúdo. A religião em geral deve antes definir-se pela sua função para o Homem, sejam quais forem as formas que possa historicamente assumir". E, na medida em que vê a religiosidade fundada na força e necessidade de transcender por parte do Homem, não pode deixar de concluir: "Compreender a socialização como processo religioso significa definir o Homem como ser religioso" 16 .

${ }^{14}$ Para este conjunto de definições, ver J. Figl, o. c., pp. 69-70.

${ }^{15}$ Cit. in: J. Figl, o. c., p. 67.

${ }^{16}$ Cit. in: J. Figl. p. 68. Não se deve esquecer que Luckmann distingue três tipos de transcendência: as "pequenas" transcendências - transcender o espaço e o tempo; as "médias" transcendências referem-se aos outros homens; e as "grandes" transcendências. 
Neste quadro, acentuando a dinâmica constitutiva humana do transcendimento, vivida em todas as experiências concretas do transcender constante para lá da sua condição biológica, a religião aparece como constitutivo humano inegável, podendo Luckmann afirmar consequentemente que "não pode haver nenhuma sociedade sem religião" 17 .

Reencontramos deste modo a constatação de cientistas da religião que referem como "religiosos" e "religião" fenómenos que normalmente não são assim considerados. Numa compreensão funcional da religião, mesmo se se não trata de religião no sentido explícito e tradicional, são assim denominadas experiências sociais e existenciais fundamentais: fala-se da arte como "religião", do desporto como "religião", da publicidade como "religião". De facto, trata-se de realidades que têm uma função "análoga" à de uma "religião"18.

Mas, afinal, se se pensar bem, tanto as definições multidimensionais como as funcionais não são propriamente definições, mas sobretudo descrições do que se entende por religião. No fundo, pressupõem o conhecimento do que é a religião, tanto mais quanto outros domínios da realidade não religiosa contêm elementos e aspectos que caracterizam a religião: doutrinais, rituais, éticos... Será, pois, necessário perguntar: qual é o critério decisivo para determinar o que é realmente a religião?

Precisamente aqui surgem então as definições ditas substantivas, que querem dizer a essência e as características determinantes da religião. Há hoje acordo entre os especialistas no sentido de verem esse critério na referência e relação com uma realidade última salvífica. São fundamentais estes dois elementos: entrada em contacto com a ultimidade, que se apresenta como dando sentido último e salvação.

3. Ao contrário da ideia corrente, no domínio religioso, Deus não é figura primeira e determinante a não ser para um determinado tipo de religião: a religião monoteísta.É célebre, neste contexto, a afirmação de Leeuw: "Deus é um fruto tardio na história religiosa" ${ }^{19}$. O conteúdo central da religião é o absoluto, o transcendente, o abrangente, o numinoso.

Quando se procura o que é comum nas diferentes religiões, distinguindo-as do que não é religioso, encontramos expressões como: a religião é a fé em seres espirituais (Tylor); a religião é "a fé em poderes transcendentes" (Richter); o fundamento da religião não é uma divindade, mas o poder, o poderoso (Nathan

\footnotetext{
${ }^{17}$ Cit. in: J. Figl, o. c., p. 68.

${ }^{18}$ J. Figl, o. c., p. 68.

${ }^{19}$ Cit. in: J. Figl, o. c., p. 67.
} 
Söderblon); a religião é "vivência de um poder superior" (Leeuw); a religião é "o confronto do Homem com um poder misterioso" (Bertholet); a religião dá-se no contexto de hierofanias e na dialéctica do sagrado e do profano (Mircea Eliade); a religião como sentimento da experiência do santo (Rudolf Otto); a religião é "o encontro vivencial com o sagrado e a acção correspondente do Homem determinado pelo sagrado" (Mensching) ${ }^{20}$.

Assim, para os fenomenólogos da religião, o Homem religioso é aquele que assume uma determinada atitude face ao Sagrado, entendendo-se por Sagrado aquele âmbito de realidade que se traduz por termos como "o invisível", "a ultimidade" "a verdadeira fonte do valor e sentido últimos", "a realidade autêntica". A religião não é em primeiro lugar ordo ad Deum, mas ordo ad Sanctum. Antes da sua configuração como deuses e Deus, o "objecto" da religião é o Sagrado, que também dá pelo nome de Mistério, que é ao mesmo tempo absolutamente transcendente e radicalmente imanente. $\mathrm{O}$ homem religioso faz a experiência do Sagrado ou Mistério enquanto Presença originante e doadora de toda a realidade. É Presença enquanto Transcendência radical no centro da realidade e da pessoa e, assim, Imanência, isto é, Presença mais íntima à realidade e à pessoa do que a sua própria intimidade. Para o Homem religioso, a realidade não se esgota na sua imediatidade empírica: para a sua compreensão adequada, a realidade mesma aparece-lhe como incluindo uma Presença que não se vê em si mesma, mas implicada no que se vê. Mediante certas características - a contingência radical, a morte e o protesto contra ela, a exigência de sentido -, a própria realidade se mostra implicando essa Presença sagrada, divina, como seu fundamento e sentido últimos.

Neste quadro, é decisiva a experiência da contingência radical do mundo, de cada homem e cada mulher, mas, como escreveu R. Panikkar, precisamente assim: contingência deriva do latim cum-tangere, com o sentido de que "tocamos (tangere) os nossos limites" e "o ilimitado toca-nos (cum-tangere) tangencialmente". Hegel, como ficou dito, também o disse: só no Infinito o finito encontra a sua verdade.

Em ordem a uma definição substantiva de religião, não se pode seguir um método apriorístico nem atender apenas a uma tradição religiosa. Como ficou dito, a própria denominação "religião" tem um sabor latino, referindo-se, em primeiro lugar, ao que os romanos entendiam como os deveres para com os deuses, para afastar os males e obter a sua ajuda e protecção, passando depois a designar o cristianismo e, a partir do Iluminismo, por extensão e no plural, um conjunto de factos e comportamentos humanos específicos, presentes em

\footnotetext{
${ }^{20}$ Para estas referências, ver J. Figl, o.c., pp. 67-68.
} 
toda a história da Humanidade, variados segundo as diferentes culturas, mas dotados de traços comuns, de tal modo que poderiam ser também denominados como religião. Assim, para lá da religião cristã, começou-se a falar, com o mesmo nome, do hinduísmo, budismo, judaísmo, islão, etc. Evidentemente, é necessário tomar consciência de que a palavra só pode ser utilizada em sentido análogo, pois outras religiões têm palavras diferentes para se autodesignarem - o hinduísmo compreende-se como sanatana Dharma: sistema ou lei eterna, o islão: submissão incondicional a Deus, etc. -, e há que evitar o perigo de colonização cultural. De qualquer modo, o uso ocidental exportou o termo, que se impôs no universo académico, de tal modo que Derrida falará da "mundialatinização" da "religião"21.

Consciente da complexidade e dificuldade da questão, a fenomenologia constata, por comparação, que, apesar da variedade inegável das religiões, há características e traços comuns, de tal modo que é possível estabelecer uma estrutura significativa presente e aplicável a todas. A religião surge então como termo técnico, descrevendo e compreendendo factos muito variados e diferentes, tradicionalmente estudados pelas ciências das religiões, que podem e exigem ser estudados com nome análogo, precisamente por causa dessa estrutura significativa comum. Esta estrutura comum do fenómeno religioso, presente na variedade das religiões, pode ser resumida nestes termos: um facto humano específico, presente numa pluralidade de manifestações históricas, que têm em comum: "estar inscritas num âmbito de realidade original designado pelo termo o sagrado; constar de um sistema de mediações organizadas - crenças, práticas, símbolos, lugares, tempos, objectos, sujeitos, etc. - , nas quais se expressa uma experiência humana de reconhecimento, adoração, entrega, referida a uma realidade transcendente, ao mesmo tempo que imanente, ao homem, e que intervém na sua vida para dar-lhe sentido e salvá-lo."22

A religião enquadra-se na experiência radical de dependência, implicando, portanto, na sua compreensão estrita, um núcleo com dois pólos: um pólo objectivo, constituído pela presença de uma realidade superior de que se depende, e um pólo subjectivo, que consiste na atitude de reconhecimento dessa realidade por parte do Homem. Neste contexto, P. Schebesta apresenta uma definição paradigmática: "A religião é o reconhecimento consciente e operante de uma verdade absoluta ('sagrada') da qual o Homem sabe que depende a sua

${ }^{21}$ José María Mardones, "Un vocablo para un fenómeno”, in: Imágenes de la fe 395 (2005) 6-7.

22 Velasco, Dicionário, p. 651. 
existência"23. É a partir deste núcleo que se entendem os múltiplos elementos visíveis das religiões: crenças, ritos, instituições, espaços e tempos sagrados, etc., diferentes segundo as culturas e tempos históricos humanos e unidos pelo facto de constituírem mediações religiosas. Na sua variedade, as diferentes definições de religião têm um elemento comum que as caracteriza e autentica: "apontam para uma entidade meta-empírica determinante da atitude humana como base da estrutura da religião. É o último necessário que adopta formas e nomes distintos: o santo, o misterioso, o divino, o sobrenatural. Numa palavra, um algo outro que não é coberto inteiramente com os termos que designam as coisas que o Homem tem à mão." ${ }^{24}$

4. Quando se fala de religião, percebe-se que religioso e sagrado não se identificam, "não são sinónimos" 25 . Trata-se de realidades distintas, pois religioso refere-se ao pólo subjectivo, isto é, ao movimento de transcendimento e entrega confiada a uma realidade sagrada - o pólo objectivo - o Sagrado ou Mistério. Embora distintas, diferenciam-se do profano, já que o religioso indica o modo concreto e peculiar de assumir a existência na perspectiva do Sagrado.

As diferentes formas de religião coincidem na remissão do Homem para essa realidade superior a ele e que, num primeiro momento, se pode caracterizar como um supra e um prius (U. Bianchi). Na tentativa de explicitar a definição apresentada, Juan Martín Velasco, um dos maiores especialistas no domínio da fenomenologia da religião, desenvolve os elementos ou traços essenciais do conteúdo dessa realidade misteriosa ${ }^{26}$.

Em primeiro lugar, deve-se sublinhar a sua "absoluta transcendência" em relação ao homem e ao mundo. Essa transcendência exprime-se nas várias religiões, referindo a sua "outridade": "totalmente outro"; a sua inacessibilidade: "altíssimo"; invisibilidade: "tu és um Deus escondido"; incognoscibilidade: "superincognoscível"; radical e absoluta diferença: "distinto do conhecido e do desconhecido"; a inefabilidade: dele só se pode dizer: "não é assim, não é assim"; a sua superioridade absoluta: "superior summo meo". Por isso, o homem religioso, na sua presença, sente pavor e tremor, indignidade radical. Trata-se do mysterium tremendum, como refere Rudof $\mathrm{Otto}^{27}$. p. 94 .

${ }^{23}$ Cit. Juan de Sahagún Lucas, Fenomenología y filosofía de la religión, Madrid, 1999,

${ }^{24}$ Id., o. c., p. 95.

${ }^{25}$ Id., $o . c .$, p. 96.

${ }^{26} \mathrm{Cf}$. a sua obra fundamental: Introducción a la fenomenología de la religión, Madrid, 2006,

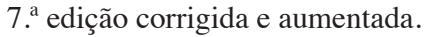

${ }^{27}$ R. Otto, Lo santo. Lo racional y lo irracional en la idea de Dios, Madrid, 2001, pp. 21-44. 
Mas, por paradoxal que pareça, o Mistério compreende simultaneamente "a sua mais perfeita imanência" ao homem e ao mundo. É próximo - o Alcorão diz que Alá é mais próximo ao homem que a sua própria jugular - e íntimo interior intimo meo, diz Santo Agostinho; no interior da transcendência, dá-se a "identidade": "tu és isso", atman é Brahman, "o centro da alma é Deus". Estes dois traços implicam-se mutuamente. De facto, "só o absolutamente transcendente pode ser imanente de forma absoluta" ou, como diz Nicolau de Cusa, só o totalmente outro é non aliud, não outro ${ }^{28}$.

O terceiro traço essencial do Mistério é "a sua condição de sujeito activo". Ele revela-se, dá-se a conhecer, interpela o Homem, atrai-o. A sua presença é anterior à procura do Homem, de tal maneira que Pascal pôde, com razão, escrever: "não me procurarias, se não me tivesses encontrado". Na sua presença, o Homem experiencia que não é por si nem dispõe de si, pois só é verdadeiramente no encontro e na entrega confiada a esse Mistério último. Mas, mais uma vez, paradoxalmente, esta entrega não significa de modo nenhum alienação, autoaniquilamento ou sujeição a uma heteronomia, pois, "devido à abertura radical do ser humano ao Infinito, o consentimento a este Além de si mesmo é a condição da sua realização plena" 29 . No radical descentramento de si, encontra o seu centro e a total realização de si enquanto salvação.

5. Torna-se, pois, claro que o encontro com o Sagrado ou o Mistério nunca é directo, mas sempre indirecto e mediado. O Sagrado manifesta-se ao Homem. Há algo sagrado que se mostra ${ }^{30}$. Precisamente determinados objectos ou factos da Natureza ou da História abrem o Homem a outra dimensão para lá do vulgar e quotidiano. Trata-se de realidades mundanas mediante as quais o Homem fica ou, melhor, se sente na presença do Mistério. Em última análise, são hierofanias: manifestações do Sagrado, como diz a própria palavra (do grego, hierós, sagrado, e phánein, manifestar).

Há hierofanias cósmicas, portanto, no próprio cosmos. Exemplos hierofânicos são o céu, os astros, a terra, uma pedra, certas plantas ou locais. Para o Homem religioso, é claro que todos esses elementos naturais continuam a ser o que eram, portanto, naturais, mas apontam para outra realidade, para um poder estranho, o Sagrado. É deste modo que aparece a distinção entre o

28 Juan Martín Velasco, "Religión”, o.c., p. 652.

${ }^{29}$ Id., o. c., p. 653.

${ }^{30}$ Mircea Eliade, O Sagrado e o Profano, Lisboa, s/d, p. 25: "O homem toma conhecimento do sagrado, porque este se manifesta, se mostra como qualquer coisa de absolutamente diferente do profano". 
mundo sagrado e o mundo profano (de pro-fanum, fora e frente ao templo, ao sagrado). Neste sentido, escreveu Mircea Eliade, de modo esclarecedor: “... algo de sagrado se nos mostra. (...) A partir da mais elementar hierofania por exemplo, a manifestação do sagrado num objecto qualquer, uma pedra ou uma árvore - e até à hierofania suprema que é, para um cristão, a encarnação de Deus em Jesus Cristo, não existe solução de continuidade. Encontramo-nos diante do mesmo acto misterioso: a manifestação de algo "de ordem diferente" - de uma realidade que não pertence ao nosso mundo - em objectos que fazem parte integrante do nosso mundo 'natural', 'profano'." Mas "a pedra sagrada, a árvore sagrada não são adoradas como pedra ou como árvore; são-no justamente porque são hierofanias, porque 'mostram' qualquer coisa que já não é pedra nem árvore, mas o sagrado, o 'ganz andere"" 31.

Exemplo célebre de hierofania é a da sarça ardente, descrita no Livro do Êxodo. "Moisés estava a apascentar o rebanho de Jetro, seu sogro, sacerdote de Madian. Conduziu o rebanho para além do deserto, e chegou à montanha de Deus, ao Horeb. O anjo do Senhor apareceu-lhe numa chama de fogo, no meio da sarça. Ele olhou e viu, e eis que a sarça ardia no fogo mas não era devorada. Moisés disse: 'Vou adentrar-me para ver esta grande visão: por que razão não se consome a sarça?' O Senhor viu que ele se adentrava para ver; e Deus chamou-o do meio da sarça: 'Moisés! Moisés!' Ele disse: 'Eis-me aqui!' Ele disse: 'Não te aproximes daqui; tira as tuas sandálias dos pés, porque o lugar em que estás é uma terra santa.' E continuou: 'Eu sou o Deus de teu pai, o Deus de Abraão, o Deus de Isaac e o Deus de Jacob.' Moisés escondeu o seu rosto, porque tinha medo de olhar para Deus" ${ }^{32}$. Aliás, Deus é invisível, como diz outro passo célebre do Êxodo: Deus disse a Moisés: "Tu não poderás ver a minha face, pois o homem não pode contemplar-me e continuar a viver." O Senhor disse: "Está aqui um lugar próximo de mim; conservar-te-ás sobre o rochedo. Quando a minha glória passar, colocar-te-ei na cavidade do rochedo e cobrir-te-ei com a minha mão, até que Eu tenha passado. Retirarei a mão, e poderás então ver-me por detrás. Quanto à minha face, ela não pode ser vista." ${ }^{33}$

As hierofanias são, pois, "um conjunto de realidades de todo o tipo cuja função consiste em presencializar, tornar presente, diante do Homem, o Mistério. Este nem se objectiva nem se mundaniza, mas dá-se a conhecer mediante

\footnotetext{
${ }^{31}$ Mircea Eliade, o. c., pp. 25-26.

${ }^{32}$ Ex. 3, 1-6.

33 Ex. 33, 20-23.
} 
objectos que remetem o Homem para outra espécie de realidade"34: o Sagrado, o Mistério, o Divino.

Neste contexto, é evidente que a única linguagem própria do universo religioso é o símbolo em sentido próprio e profundo: "um símbolo é aquilo através do qual se conhece algo distinto dele. Um símbolo serve de intermediário para o conhecimento de algo diferente." É pela sua estrutura tensa e dinâmica que o símbolo impulsiona o espírito a dirigir-se para e alcançar um significado ulterior que se encontra no próprio símbolo. Mas "só mediante uma participação activamente comprometida pode a mente humana alcançar um significado mais profundo que o empírico ou mais elevado que o terreno." ${ }^{35}$ Deste modo, numa realidade mundana tem lugar uma transsignificação: pense-se, por exemplo, na Eucaristia cristã, na qual, em relação ao pão e ao vinho, na dinâmica celebrativa, se realiza precisamente uma transsignificação, transvalorização e transfinalização, de tal modo que, na celebração, se entra em contacto com o mistério do Reino que Jesus anunciou e é.

O símbolo manifesta de modo sensível o sagrado. Neste contexto, tornase claro que Jesus é, na perspectiva cristã, o verdadeiro "símbolo de Deus": "As pessoas encontraram Deus em Jesus, ainda acontece o mesmo. (...) Jesus é a mediação da presença de Deus para o cristianismo" ${ }^{36}$.

6. O Sagrado é o mistério da realidade na sua ultimidade.

$\mathrm{Na}$ experiência do sagrado, o homem está sempre em presença de algo outro e superior, o tremendo e fascinante, o Absoluto, inabarcável, inacessível e inefável. Esta superioridade do sagrado manifesta-se em três níveis diferentes: o ontológico - infinita riqueza de ser -, axiológico - realidade sumamente valiosa - e pessoal. "Os três comportam uma ruptura de nível que aponta para a plenitude de ser e realidade por excelência"37. Assim, o Homem religioso refere-se sempre a essa ultimidade, mas, pela sua própria definição, não pode alcançá-la, menos ainda, dominá-la ou possuí-la. Percebe-se, pois, que o Sagrado seja figurado e representado de múltiplas formas nas diferentes religiões.

6.1. Uma das figuras ou representações é a de Ser supremo. Aparece, portanto, como o Deus celeste, criador e senhor das criaturas.

6.2. Quanto ao politeísmo, será necessário compreender que houve quem o interpretasse como uma degenerescência ou queda do monoteísmo. Realmente,

\footnotetext{
34 Juan de Sahagún Lucas, o.c., p. 109.

${ }^{35}$ Roger Haight, Jesus, símbolo de Dios, Madrid, 2007, p. 21.

${ }^{36}$ Id., o. c., p. 27.

37 Lucas, o.c., p. 101.
} 
o monoteísmo em sentido estrito é recente, o que não significa que haja religiões propriamente politeístas. O politeísmo é sobretudo a atribuição da Força divina originária a várias divindades, que aparecem como suas "personificações".

6.3. No quadro de tentativas de compreensão do mal, surgiram representações dualistas - pense-se no mazdeísmo, gnosticismo e maniqueísmo. Mas dificilmente se poderá dizer que haja um verdadeiro dualismo no sentido de dois princípios simétricos e supremos. Pode é dar-se uma espécie de luta no interior do Uno, com expressão no mundo e na história, que seriam a continuação desse combate a caminho da reconciliação e da vitória do Bem.

6.4. O monismo - pense-se em certas formas de hinduísmo e no budismo acentua a unidade. Este acento no Sagrado como absoluto leva a considerá-lo como realidade única, de que os outros seres, especialmente o Homem, não são senão expressões e manifestações. Precisamente a plenitude do Absoluto tenderá, por um lado, a sublinhar a unidade, mas, por outro, a diluir a dimensão pessoal $^{38}$.

${ }^{38}$ Edward Schillebeeckx, “A identidade cristã: desafio e desafiada. A propósito da extrema proximidade do Deus não-experimentável”, , in: Anselmo Borges (Coord.), Deus no século XXI e o futuro do cristianismo, Porto, 2007, pp.413-414, aponta claramente para esta diferença entre as aproximações ocidental e oriental ao mesmo problema: “As duas aproximações exprimem-se, no que se refere à transcendência, no quadro de uma teologia negativa. Quanto ao sentido da existência humana, distinguem-se segundo duas atitudes de vida diferentes; de um lado, uma espécie de transcendência do vazio (em sânscrito: shûnyatta; em Pâli: sunnatâ), do outro, nas três religiões monoteístas, uma transcendência que transcende o ser humano por superabundância, uma transcendência que, além disso, não pode ser atingida pela razão humana. É uma transcendência de plenitude na qual ou, mais justamente, em Quem tudo o que vive e se move pode existir. As duas experiências diferem, mas essas diferenças são expressas em conceitos ou imagens que não fazem plenamente jus às duas experiências. Há um excesso não expressável. As visões monoteístas - judaísmo, cristianismo e islão - exprimem Deus como 'pessoal'; eu não digo 'como pessoa', porque só conhecemos o ser humano como pessoa. Nestas religiões, a oração é também possível: Deus é abordável e podemos dirigir-nos a ele. O silêncio de Deus, quando nos dirigimos a ele, leva os crentes que têm confiança em Deus a respostas humanas numa interpretação. As religiões não monoteístas falam de nirvana, vazio, e mesmo de nothingness ('nada'). Neste plano, diálogos directos são possíveis entre cristãos ocidentais e hindus ou budistas orientais ou representantes de outras religiões asiáticas. Mas com a condição de todos os parceiros perceberem bem que as imagens do ser humano e do mundo de todas as religiões diferem entre si. (...) Um diálogo inter-religioso é assim bem mais difícil do que muitos pensam, mas faz parte integrante da nossa tarefa teológica."

Sobre esta problemática tão complexa do Absoluto como pessoal ou apessoal, ver: Hans Küng et alii, El cristianismo y las grandes religiones, Madrid, 1987, pp. 444-472; Juan Martín

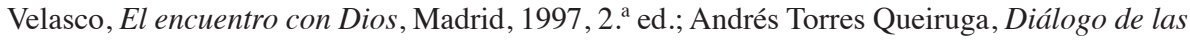
religiones y autocomprensión cristiana, Santander, 2005, pp. 116-122. Também trato da questão em: Anselmo Borges, Corpo e transcendência, Porto, 2003, pp. 221-229. 
6.5. O monoteísmo, enquanto figuração do Sagrado como um único Deus transcendente, pessoal e criador, é, na história das religiões, bastante recente, podendo afirmar-se que só alcançou expressão no tempo do exílio na Babilónia ${ }^{39}$.

Neste contexto, poderá dizer-se que, no panorama da história das religiões, analisando a lógica da sua evolução e o que estruturalmente as une, desde a pré-história até ao presente, as duas opções religiosas fundamentais são o monismo e o monoteísmo ${ }^{40}$.

7. Frente ao Sagrado, o Homem religioso vive a sua vida na perspectiva da transcendência em ordem a encontrar a plena realização da sua existência e adopta um conjunto de atitudes ${ }^{41}$.

A atitude fundamental é a vivência da própria existência enquanto recebida como dom desse Ser transcendente. Mas ela explicita-se em comportamentos concretos, dos quais o primeiro é certamente a fé enquanto entrega confiada ao Sagrado enquanto fonte de plenitude e salvação.

A fé, por sua vez, requer e traduz-se em práticas religiosas. A oração é certamente a prática mais imediata, não no sentido primeiro de implorar favores, mas de encontro e diálogo com essa realidade que se impõe com uma tríplice superioridade, como se disse: ontológica, axiológica e pessoal - pessoal, no quadro da experiência monoteísta. A oração, que tem também como momento essencial o louvor, alcança o seu cume na experiência mística.

${ }^{39}$ Como escreveu José Gómez Caffarena, El enigma y el Misterio, p. 116, essa experiência negativa de submissão ao Império babilónico, com a destruição (ano 587 a. C.) do templo de Salomão e deportação para a Babilónia, "foi, paradoxalmente, positiva para o monoteísmo javista, que alcançou nesse tempo plena expressão (sobretudo nos escritores 'deuteronomistas' e no grande profeta do exílio que anunciou o regresso e cujos textos formam os capítulos 40-55 do livro de Isaías, pelo que se costuma chamar 'segundo Isaías'). Foi chave a abertura de um horizonte universal, exigida logicamente pela unicidade de Deus proclamada pelo monoteísmo, que implicava a superação (relativa) do particularismo etnicista inerente às ideias de eleição e 'aliança'”. Cf. também: Régis Debray, Dieu, un itinéraire, Paris, 2001, pp. 29-55.

${ }^{40}$ Esta é a tese de Karl-Heinz Ohlig, Religião. Tudo o que é preciso saber, Lisboa, 2007.

Neste quadro, compreende-se que, no limite, por paradoxal que pareça, possa haver e haja de facto quem seja ao mesmo tempo religioso e ateu.É religioso porque vive vinculado ao Sagrado, àquela Ultimidade que o Homem não domina nem possui. Mas, por outro lado, ateu, porque, figurando o Sagrado ou a Ultimidade como anónimo(a) - pense-se, por exemplo, na Natureza, não enquanto Natureza naturada, mas enquanto Natureza naturante, Força e Fonte divina impessoal donde procede tudo quanto vem à luz, ou na sociedade futura finalmente reconciliada e sem contradições -, não pode haver uma relação pessoal com ele ou com ela, não se lhe pode rezar nem se espera a salvação num encontro pessoal.

${ }^{41}$ Cf. Lucas, o. c., pp.136-140. 
Outras práticas e comportamentos religiosos estão em conexão com categorias religiosas essenciais, como: festas e culto, sacrifícios, pecado, culpa e perdão, morte e imortalidade.

Todas as religiões têm dias especiais nos quais há como que a suspensão do quotidiano e das tarefas normais para dedicar-se a Deus. É sobretudo nesses dias festivas que se realizam os actos de culto litúrgicos.

Nos sacrifícios, como diz a etimologia - sacrum facere (tornar sagrado) -, o Homem religioso introduz algo de profano no sagrado, para aprofundar os seus vínculos com o Sagrado. O Homem religioso oferece dons, reconhecendo a sua dependência, expia os pecados, entra em comunhão com o Sagrado, o Divino.

O homem religioso sabe que transgride a ordem da vontade divina. Reconhece-se, pois, pecador e implora perdão, num movimento de arrependimento e conversão.

A experiência da morte abala radicalmente o ser humano, que procura salvação e imortalidade na entrega religiosa confiada. Esta imortalidade é, evidentemente, interpretada de modos diferentes, segundo as várias religiões.

De qualquer forma, compreende-se que, se todas as religiões estão referidas ao Sagrado enquanto Mistério último, que a todas reúne, o diálogo inter-religioso é exigido não apenas como exigência para a paz, mas pela própria dinâmica religiosa na sua compreensão autêntica e profunda.

\section{II}

O que desde há anos Hans Küng vem sublinhando - a necessidade do diálogo inter-religioso para ser possível a paz no mundo - é cada vez mais urgente. Entende-se mais claramente do que nunca que a obra do célebre teólogo, autor principal da "Declaração de uma Ética Mundial”, aprovada pelo Parlamento Mundial das Religiões em Chicago em 1993, se oriente pelo lema: "Não haverá paz entre as nações sem paz entre as religiões. Não haverá paz entre as religiões sem diálogo entre as religiões. Não haverá diálogo entre as religiões sem critérios éticos globais. Não haverá sobrevivência do nosso globo sem um ethos global, um ethos mundial" ${ }^{2}$.

${ }^{42}$ Hans Küng, Spurensuche. Die Weltreligionen auf dem Weg, Munique, Zurique, 1999, 2. ${ }^{a}$ ed., p. 306. 
Antes de entrarmos directa e explicitamente na questão do diálogo interreligioso, será importante debater alguns pontos prévios, que podemos considerar condições de possibilidade para esse diálogo: religião e violência, a questão do fundamentalismo, a problemática da revelação e da leitura dos livros considerados sagrados, a secularização no sentido da separação da(s) Igrejas e do Estado.

1. É demasiado complexa a relação entre a religião e a violência, referindo-se aqui apenas a dinâmica profunda que pode explicar a violência religiosa enquanto tal.

Desde que toma consciência de si mesmo, o ser humano vive em sobressalto: independentemente da questão de saber se é mais dominado pela angústia ou pela esperança, está, de modo mais ou menos consciente, pela morte, constitutivamente confrontado com a possibilidade do nada - nunca mais ser. A consciência da morte tem o condão de revelar ao Homem de modo brutal e sem apelo a sua radical impotência: não é o seu próprio fundamento, em última análise não pertence a si e está permanentemente sob a ameaça de deixar de ser. Esta consciência provoca angústia, pois o confronto com o nada é simplesmente horroroso e laminante.

Se, como viu Espinosa, todo o ser quer por natureza manter-se no ser - é o famoso conatus sui-, percebe-se que uma das estratégias mais comuns para superar a angústia da morte, que é angústia do nada, seja o poder e a sua acumulação sem freio: poder económico, poder político, poder sexual, poder religioso - concupiscência da carne, concupiscência dos olhos, soberba da vida, como diz a Bíblia. Pelo poder enquanto domínio sobre coisas e pessoas - a estratégia é tanto mais eficaz quanto mais extenso e pleno for o poder, até à tentação do poder total, e não se pode esquecer que pela sua própria dinâmica o poder quer ser total -, tem-se a ilusão, consciente ou inconsciente, de dominar a morte. De dominado pela angústia da morte passa-se então a seu senhor. O poder pode aparecer como bênção de imortalidade: na embriaguez do poder, aninha-se a ilusão de matar a morte.

Aqui, essencialmente, radica o vínculo fundamental entre religião, poder e, consequentemente, violência. Observa-se, de facto, na história das religiões, uma luta permanente no sentido de saber qual delas tem o Deus mais poderoso. Na sua elaboração filosófica, Deus surge com o atributo da omnipotência, entendida até frequentemente de modo infantil: Deus pode tudo, até o que é contraditório, de tal modo que os crentes se sentem perplexos e perturbados, se lhes perguntam se Deus também pode - era o famoso paradoxo medieval criar uma pedra tão grande e pesada com a qual depois não possa, fazer com 
que dois mais dois sejam cinco ou cometer suicídio... Para que é que serviria um Deus que não fosse "o Deus dos exércitos" e a própria Omnipotência? Mas, depois, quando o crente julga ter do seu lado o Deus omnipotente, o que vai ou não vai fazer com ele ou, pelo menos, em seu nome?

Está aqui presente o perigo do horror bruto da ligação entre religião e violência. Julgando apoderar-se de Deus infinito e omnipotente, o Homem finito e mortal encontra finalmente a segurança: nada pode abalá-lo, e, por isso, está feliz. Mas, depois, no encontro com outras crenças, outras formas de religião, modos outros de conceber e relacionar-se com o mesmo Deus infinito e omnipotente - em última análise, o Sagrado, como vimos -, é como se as estruturas de segurança desabassem outra vez: como é que Deus pode apresentar-se a outros de modo diferente? As outras religiões surgem, pois, como ameaça radical: roído pela dúvida na relação com o Infinito, o crente vê-se outra vez mortal, inseguro e infeliz. É intolerável que Deus se revele de muitos modos, quando cada um o considera propriedade exclusiva. Neste domínio, a dúvida é devoradora: o confronto com a alteridade religiosa repõe o medo e a desorientação. A guerra religiosa tem aqui a sua base, se é que há guerras exclusivamente religiosas ${ }^{43}$.

2. Assim, numa primeira leitura, a guerra religiosa justifica-se em nome da verdade. Mas é necessário acrescentar que com esse interesse pela "verdade" andam misturadas muitas outras camadas de interesses outros: segurança individual e colectiva, legitimação social, conquista de territórios e mercados, histórias de ajuste de contas, numa palavra, o poder. Insere-se aqui a questão do fundamentalismo.

De modo geral, quando se fala em fundamentalismo, é no fundamentalismo religioso que se pensa. Há, porém, outras formas de fundamentalismo: o fundamentalismo político, o fundamentalismo cultural, o fundamentalismo económico, por exemplo. Joseph Stiglitz, Prémio Nobel da Economia, referindo-se à política económica seguida pelo FMI no quadro da globalização, fala de "fundamentalismo neoliberal".

Quando se refere o fundamentalismo religioso, pensa-se essencialmente no islão ${ }^{44}$. Mas, de facto, as palavras "fundamentalismo" e "fundamentalista" nasceram nos Estados Unidos, nos princípios do século XX e no contexto do

43 Retomo aqui o essencial de "Morte, religião e violência", in: Anselmo Borges, Religião: opressão ou libertação?, Porto, 2004, pp. 205-206.

${ }^{44}$ Utilizo o termo islão, para distinguir de islamismo, que significa a atitude de quem se serve do islão de modo fundamentalista. 
protestantismo. Com o objectivo de preservar e defender os pontos considerados fundamentais da fé cristã, protestantes evangélicos norte-americanos de várias denominações escreveram artigos teológicos que foram reunidos e publicados entre 1910 e 1915, em doze fascículos com o título The Fundamentals: a Testimony to Truth, numa edição de três milhões de exemplares. Em 1919, foi criada a World's Christian Fundamentals Association, na convicção de que a regeneração do protestantismo implicava o combate ao liberalismo teológico. Foi em 1920 que o termo passou à opinião pública através de um artigo de Curtis Lee Laws, no qual se lia: "Sugerimos que aqueles que ainda continuam firmemente apegados aos grandes fundamentos (Fundamentals) e que estão decididos a combater a sério por esses fundamentos sejam chamados Fundamentalists", devendo, portanto, o termo ser considerado "um elogio e não um insulto".

Um dos fundamentos inquestionáveis era o da inspiração verbal da Bíblia, seguindo-se daí a sua infalibilidade e inerrância. O texto bíblico devia ser assumido à letra e a sua autoridade estendia-se não só ao domínio religioso mas também a todos os campos do saber: científico, histórico, filosófico. Foi neste contexto que em 1925 teve lugar em Dayton o famoso "caso Scopes": um jovem professor de biologia, John T. Scopes, foi julgado e condenado por ensinar aos alunos a teoria da evolução das espécies de Darwin. Esse debate à volta do ensino do evolucionismo e da narração bíblica da criação nas escolas continua ainda hoje nos Estados Unidos ${ }^{45}$.

Há várias explicações para o fundamentalismo, que cultiva o pensamento único e a intolerância. Sublinham-se três.

Quando se não suporta viver na perplexidade e na interrogação, surge a tentação de absolutizar as próprias crenças, excluindo e perseguindo quem as não partilha.

Em toda a História foi permanente a utilização da religião para fins que não são os seus: alcançar o poder, servir os próprios interesses económicos, políticos, culturais, impor hegemonicamente o próprio domínio.

Em última análise, na base está uma determinada concepção de verdade, que se confunde com a posse do Fundamento. Mas, precisamente aqui, é preciso perguntar: quem é o Homem, um ser finito, para considerar-se senhor do Fundamento? Ele não possui o Fundamento ou o Absoluto, é o Fundamento que o possui a ele. Isto não é relativismo, mas perspectivismo: vamos ao encontro da realidade sempre numa determinada perspectiva. Por isso, no domínio religioso,

${ }^{45}$ Juan José Tamayo, Fundamentalismos y diálogo entre religiones, Madrid, 2004, pp. $73-80$. 
há que reconhecer que há mais verdade nas religiões todas do que numa só, e dessa verdade faz também parte a pergunta pelo ateísmo.

3. A questão do fundamentalismo religioso acaba por desembocar na problemática da revelação e dos livros considerados sagrados.

Lê-se em Josué, um dos livros da Bíblia, capítulo 10, versículos 12-13: "No dia em que o Senhor entregou os amorreus nas mãos dos filhos de Israel, Josué falou ao Senhor e disse, na presença dos israelitas: 'Detém-te, ó Sol, sobre Guibeon'. E o Sol parou no meio do céu e não se apressou a pôr-se durante quase um dia inteiro."

Este é o passo famoso que deu origem à oposição dos representantes da Igreja a Galileu e à ciência. Como podia ser a Terra a girar, se a Bíblia diz que o Sol parou? Mas já na altura Galileu foi mais avisado do que os seus opositores, quando contrapôs que a Bíblia não nos diz como é o céu mas como se vai para o Céu.

Que a leitura dos livros sagrados não pode ser literal mostra-se inclusivamente pelo facto de eles conterem erros científicos no domínio da física, da astronomia, da história. Pense-se, por exemplo, em todos os debates cegos à volta do Génesis e concretamente do mito da criação, quando se não percebe que não se trata de informação científica de física ou biologia, mas de uma mensagem religiosa em linguagem mítica: James Usher, arcebispo de Armagh e primaz de toda a Irlanda (1581-1656) pretendeu saber a data da criação da Terra - 23 de Outubro de 4004 a. C. - - tendo Bertrand Russell observado corrosivamente que esse dia caiu numa Sexta-Feira, já que Deus descansou no Sábado! Há também o caso risível de um teólogo de Münster que, no século XIX, pretendeu apresentar uma prova "científica" da existência do inferno no interior da Terra, argumentando com os vulcões! É claro que teologias ridículas como estas só podem contribuir para o aumento do número dos ateus.

Os livros sagrados não estão sequer imunes a imoralidades. Não é preciso ser especialmente piedoso para considerar particularmente impiedosa esta impetração bíblica, no Salmo 137: "Cidade da Babilónia devastadora, feliz de quem te retribuir com o mesmo mal que nos fizeste! Feliz de quem agarrar nas tuas crianças e as esmagar contra as rochas!" Como atribuir a Deus o que não conseguimos pensar de um ser humano bom e decente? O exegeta N. Lohfink assevera que o Antigo Testamento "é um dos livros mais cheios de sangue da literatura mundial”"46. Quanto ao Alcorão, não será necessário referir

${ }^{46}$ N. Lohfink/R.Pesch, Weltgestaltung und Gewaltlosigkeit, Düsseldorf, 1978, p. 13. Cit. in: J. Tamayo, o.c., p. 91 . 
a famosa jihad e a compreensão terrorista enquanto guerra santa que dela têm os islamistas radicais.

4. Aqui, coloca-se um outro problema, decisivo para o diálogo inter-religioso e a paz no mundo, precisamente o da revelação, categoria essencial no domínio religioso, pois todas as religiões se entendem a si mesmas como reveladas. A pergunta é: como sabem os crentes que Deus falou?

Em certos debates sobre a fé e a ciência, pode-se penosamente constatar que os cientistas têm frequentemente a ideia de que a fé tem a ver com umas crenças indiscutíveis, porque cegas, em coisas e "verdades" abstrusas, de tal modo que quanto mais abstrusas mais religiosas e a fé seria tanto maior quanto mais cega.

A culpa nem sempre é deles, mas dos crentes que passam essa ideia. Pensa-se, de facto, de modo geral, que as religiões caem do céu, havendo até quem julgue que Deus revelou directamente verdades nas quais é preciso acreditar sem razões.

Ora, não é assim nem pode ser. Tudo o que é autenticamente religioso é resposta humana a questões e perguntas profunda e radicalmente humanas. Resposta verdadeiramente humana. A sua especificidade reside no facto de estar relacionada com Deus. Assim, um texto religioso tem sempre na sua base uma interpretação humana da realidade, da única realidade que há, comum a crentes e a não crentes. O que se passa é que o crente tem a convicção de que a realidade se não esgota na sua imediatidade empírica, e essa convicção não surge porque é crente, mas porque a realidade mesma, para a sua compreensão adequada, lhe aparece incluindo uma Presença que não se vê em si mesma, mas implicada no que se vê. Mediante certas características - a contingência radical, a morte e o protesto contra ela, a exigência de sentido -, a própria realidade se mostra implicando essa Presença divina como seu fundamento e sentido últimos.

Assim, como escreve Andrés Torres Queiruga, na estrutura íntima do processo religioso, "não se interpreta o mundo de uma determinada maneira porque se é crente ou ateu, mas é-se crente ou ateu porque a fé ou a não crença aparecem ao crente e ao ateu, respectivamente, como a melhor maneira de interpretar o mundo comum" 47 .

A fé, no seu nível próprio, tem razões, de tal modo que está sujeita à verificação. Há Teologia, precisamente porque a fé exige o debate público.

${ }^{47}$ Andrés Torres Queiruga, "Diálogo ciência-fé na actualidade", in: Anselmo Borges, Deus no século XXI, p. 228. 
Aí, o agnóstico dirá que não vê razões para poder decidir-se. $\mathrm{O}$ ateu julga que as razões contrárias são mais fortes e, por isso, não crê. Para o crente, a "hipótese religiosa" é a que melhor esclarece as experiências e questões radicais postas pela realidade e pela existência: a contingência, as perguntas últimas pela vida e pela morte, a esperança, a exigência ética, o sentido da História.

A partir de uma experiência religiosa de fundo por parte do profeta ou do fundador religioso, desencadeia-se um processo vivo de aprofundamento, depuração e tentativas de maior compreensão da relação com o Divino, que dá origem a tradições religiosas ou religiões que acabam por sedimentar ou cristalizar em livros sagrados, considerados "revelados".

Esse carácter "revelado" dos textos aparece de facto mais tarde, quando, mediante a reflexão, as gerações seguintes concluem que afinal aquela descoberta da presença de Deus na realidade foi possível porque o próprio Deus estava desde sempre a manifestar-se nela e a tentar dar-se a conhecer. O profeta ou o fundador descobriram o que Deus quer revelar a todos.

Assim, os novos crentes não aceitam a verdade da fé por via autoritária. Eles próprios a comprovam. Paradoxalmente, é o que acontece no domínio científico: todos tinham visto as maçãs a cair, mas só Newton "caiu na conta" da lei da gravidade; porém, uma vez descoberta, todos a aceitam, não por causa de Newton, mas porque todos podem comprová-la.

Andrés Torres Queiruga, o teólogo que de modo mais penetrante tentou esclarecer esta questão, chamou a esta compreensão "maiêutica histórica". Sócrates chamou maiêutica ao seu método de descoberta da verdade: como a sua mãe, que era parteira, ajudava a dar à luz os bebés, assim ele ajudava os seres humanos a dar à luz a verdade de que estavam grávidos. Na verdade religiosa, há os profetas e os fundadores das religiões, que foram os primeiros a tomar consciência da verdade. Mas, após essa descoberta, ouvindo-os e acompanhando-os, outros se podem dar conta por si mesmos da mesma verdade ${ }^{48}$.

Portanto, Deus manifesta-se, mas nunca directamente, sempre e só indirectamente. Jamais alguém viu ou falou directamente com Deus. Por isso, os livros sagrados não são um ditado divino - são Palavra de Deus em palavras humanas. Quer os seus autores quer os seus leitores escreveram e lêem com uma précompreensão, isto é, no quadro de pressupostos históricos e culturais, interesses e expectativas. Portanto, a sua leitura nunca pode ser literal, pois implica sempre uma interpretação.

${ }^{48}$ Andrés Torres Queiruga trata esta questão em múltiplas obras, mas a principal é: La revelación de Dios en la realización del hombre, Madrid, 1987. 
Torna-se, pois, claro que os livros sagrados - a Bíblia, o Alcorão e todos os outros - não são ditados divinos e precisam, por isso, de uma mediação hermenêutica, não podendo de modo nenhum - exige-o o respeito para com o próprio Deus - ser engolidos na sua totalidade de modo acrítico.

Um dos contributos decisivos da modernidade consistiu na leitura histórico-crítica dos livros sagrados. Albert Schweitzer, teólogo, filósofo, médico, músico, Prémio Nobel da Paz, tinha razão ao escrever que o empreendimento da crítica bíblica representa "a coisa mais poderosa que alguma vez a reflexão religiosa ousou e realizou" 49 . É esperável que a abertura a uma hermenêutica histórica e crítica do Alcorão, a partir de uma longa tradição no Islão, que faz apelo à ijtihad - um princípio permanente de interpretação -, possa começar a abrir caminho também no mundo muçulmano, concretamente com "os novos pensadores do Islão". Evidentemente, nesta história da leitura crítica dos livros sagrados, não podem ser esquecidos os grandes iniciadores como Averróis, pelo lado islâmico, e Espinosa, pelo lado hebraico.

Nos livros sagrados - daí o seu valor - condensam-se respostas à pergunta decisiva do Homem, que é a questão do fim, do sentido e finalidade últimos da existência e do mundo. Mas torna-se evidente a urgência em ir ao seu encontro de modo crítico e saudável.

A verdade de qualquer livro sagrado só pode acontecer na compreensão de que o seu horizonte é a salvação. Os livros sagrados são livros religiosos voltados para a oferta da salvação.

Se toda a religião tem como ponto de partida e de "definição" esta pergunta essencial: o quê ou quem traz libertação e salvação?, então a libertação-salvação total é que constitui o fio hermenêutico decisivo para a interpretação correcta dos livros sagrados na sua verdade final ${ }^{50}$. Só a esta luz é que eles são verdadeiros. A sua leitura nunca pode ser fragmentada, já que só no seu todo é que se reclamam da verdade. Em tudo quanto neles se encontra de menos humano ou até de desumano revela-se o que Deus não é.

À luz da libertação final, que implica uma antropologia e uma teologia negativas, os livros sagrados são também a história da tomada de consciência por parte dos seres humanos do que Deus, o Sagrado, não é e do que eles, para se tornarem verdadeiramente humanos, não devem ser.

\footnotetext{
${ }^{49}$ Albert Schweitzer, Geschichte der leben-Jesu-Forschung, Tubinga, 1984, 9. a ed., p. 45.

${ }^{50}$ Pergunta, para responder afirmativamente, Andrés Torres Queiruga, Esperanza a pesar del mal, Santander, 2005, p. 93: "Que são as religiões senão modos de configurar socialmente a descoberta do divino como esperança contra a dor, o pecado e a própria morte?"
} 
5. Precisamente neste contexto, sem deixar de interrogar-se, como faz o teólogo Juan José Tamayo, sobre se "o Ocidente pode dar lições de direitos humanos e de tolerância ao Islão", é preciso perguntar se também nos Estados muçulmanos são possíveis a separação da religião e do Estado, a interpretação crítica do Alcorão, a autonomia das realidades temporais em relação à tutela religiosa, o respeito pela liberdade de consciência, de pensamento, de expressão, de reunião, de associação, "o direito à crítica da religião", à mudança de religião e à não crença, a igualdade dos sexos e dos seus direitos, "a distinção entre ética civil e ética religiosa" ${ }^{51}$.

De facto, seja qual for o juízo que se faça sobre a modernidade e a sua crise, é necessário reconhecer conquistas suas irrenunciáveis: precisamente a leitura histórico-crítica dos textos sagrados, a separação das Igrejas e do Estado, da religião e da política, os direitos humanos, a ciência e a razão crítica, a autonomia das realidades terrestres. Apesar das constantes tentações restauracionistas e até pró-fundamentalistas, são valores que também a Igreja Católica reconheceu no Concílio Vaticano II (1962-1965), superando, no essencial, os conflitos que durante trezentos anos manteve com os tempos modernos.

"Dai a César o que é de César e a Deus o que é de Deus", foi programaticamente declarado por Jesus Cristo. Esta separação do político e do religioso não tinha sentido na Grécia, que não separava o cívico e o cultual, nem para o judaísmo, que unificava nação e religião. Como escreveu Régis Debray, em Jerusalém, Atenas e Roma, “o ritual cívico é religioso, e o ritual religioso é cívico". Para as três culturas que estão na base da nossa, alguém que estivesse fora da religião estava fora da Cidade ou do Povo. "Foi o cristianismo que inventou a religião como coisa à parte" ${ }^{\prime 2}$.

Contra o preceito de Cristo que delimitou campos de poder, Constantino, apesar da sua "conversão" ao cristianismo, não esqueceu a divinização imperial e intrometeu-se nas questões da Igreja, convocando concílios, condicionando ou mesmo determinando as suas decisões. O Papa Bonifácio VIII formulou a teoria das duas espadas, segundo a qual o Papa detém o poder espiritual e o temporal, mas, se exerce o primeiro directamente, delega o segundo nos príncipes, que o exercem em representação do Papa. Para se defenderem dos Papas, os monarcas reivindicaram o direito divino dos reis. Mesmo Lutero afirmou o carácter divino de toda a autoridade estabelecida.

A modernidade impôs a secularização, pondo fim a equívocos próprios da Cristandade e de césaro-papismos. Mesmo que se não esteja completamente

\footnotetext{
${ }^{51}$ J. Tamayo, o.c., pp. 235-236.

${ }^{52}$ R. Debray, Dieu, un itinéraire, pp. 192-193.
} 
de acordo com autores que sustentam que a secularização é um fenómeno produzido pela fé cristã, é necessário afirmar que, ainda que, de facto, tenha tido de impor-se contra a Igreja oficial, a secularização, no sentido da autonomia das realidades terrestres e concretamente da separação da Igreja e do Estado, tem raízes bíblicas.

O monoteísmo desdivinizou a política e os detentores do poder político. O profeta Ezequiel advertiu o rei de Tiro: "Tu és um homem e não um deus". Jesus deixou aquela palavra decisiva sobre Deus e César. Por isso, os cristãos opuseram-se frontalmente à divinização do imperador, proclamando que "só Deus é o Senhor" e recebendo em troca a acusação de ateísmo.

Em ordem à dessacralização da política e à consequente separação da Igreja e do Estado, foram decisivas as guerras de religião na Europa. De facto, só mediante essa separação, que significava a neutralidade religiosa do Estado, era possível a garantia da liberdade religiosa de todos os cidadãos sem discriminação. Com a desconfessionalização do Estado, os cidadãos tornaram-se livres de terem esta ou aquela religião ou nenhuma.

É, porém, importante perceber que essa exigência não deriva apenas da necessidade do estabelecimento da paz política e civil, mas da natureza do cristianismo. A própria fé impõe essa separação. De facto, sem ela, espreita constantemente o perigo de idolatria, isto é, de confusão ou até de identificação entre Deus e a política.

Um Estado confessional põe em causa a transcendência divina. Por outro lado, acaba por impor politicamente o que só pode ser objecto de opção livre. Por exemplo, ninguém nasce cristão, mas as pessoas podem livremente escolher o cristianismo. Só homens e mulheres verdadeiramente livres podem aderir à fé religiosa e a Deus.

Assim, a secularização no sentido da emancipação da razão autónoma e das esferas temporais tem fundamentos bíblicos e pertence à dinâmica adulta do cristianismo. É, no entanto, preciso tornar claro que secularização não tem que confundir-se com secularismo, termo criado pela Londoner Secular Society, fundada por G. J. Holyoake, em Londres, em 1846, cujo programa consistia resumidamente em conceber e organizar a vida prescindindo de Deus e da religião. De facto, o crente maior de idade, ao mesmo tempo que pressupõe e quer uma razão e um mundo adultos, também sabe que a secularização não elimina o Mistério, pois a finitude não é secularizável.

Neste contexto, note-se que o projecto de Tratado Constitucional Europeu, no artigo consagrado ao "estatuto das Igrejas e organizações não confessionais", previa "um diálogo aberto, transparente e regular com estas Igrejas e organizações". 
Se, por um lado, a secularização enquanto separação da(s) Igreja(s) e do Estado constitui um avanço civilizacional fundamental em ordem à não discriminação dos cidadãos e à salvaguarda da paz, por outro, ela não significa indiferença mútua. Pelo contrário, a separação pode e deve conviver de modo saudável com o reconhecimento do papel público das religiões, traduzido em múltiplas formas de colaboração entre as Igrejas e o Estado.

Na situação actual, não foi apenas a "transcendência religiosa" que perdeu vigor, também a "transcendência política" está em crise. Por isso, as sociedades liberais vêem-se a braços com a dificuldade de fundamentação dos valores e estabelecer vínculos de cidadania. Nesta linha, não faltam pensadores que fazem apelo à religião no seu papel espiritual, ético, cultural. Respeitando as autonomias individuais e o pluralismo democrático, as religiões podem dar um contributo positivo com os seus "recursos simbólicos"(J.-P. Willaime).

Precisamente face aos enormes desafios éticos com que o nosso tempo se vê confrontado, Jürgen Habermas, um dos maiores filósofos vivos, agnóstico, manifesta "interesse por uma aproximação respeitosa das tradições religiosas que se distinguem pela capacidade superior que têm de articular a nossa sensibilidade moral", aproximação que ofereceria "o exemplo de uma secularização que salva em vez de aniquilar". Para ele, nesta conjuntura, as vozes religiosas têm tanto direito a pronunciar-se como as visões laicizadas do mundo, pelo menos se aceitarem "traduzir a sua mensagem em linguagens públicas e universalmente acessíveis" ${ }^{3}$. No contexto de "um caminho para uma compreensão dialéctica da secularização cultural", escreve: "Garantir iguais liberdades éticas para todos requer a secularização do poder do Estado, mas proíbe a excessiva generalização política da concepção secularista do mundo. Os cidadãos secularizados, no exercício do seu papel de cidadãos do Estado, não podem negar por princípio um potencial de verdade às imagens religiosas do mundo, como também não podem pôr em questão o direito de os seus concidadãos crentes contribuírem, na linguagem que lhes é própria, para as discussões públicas. A cultura política liberal pode inclusivamente esperar dos cidadãos secularizados que tomem parte nos esforços de tradução da linguagem religiosa para outra linguagem publicamente acessível contributos que sejam relevantes" 54 .

${ }^{53}$ Para estas referências e citações, ver: Anselmo Borges, "Secularização e tolerância", in: Revista de História das Ideias 25 (2004) 131-138.

${ }^{54}$ J. Habermas, Naturalismus und Religion, Frankfurt/M., 2005, p. 322. Sobre esta problemática da secularização, laicidade e religião civil é incontornável a obra de Fernando Catroga, Entre Deuses e Césares. Secularização, Laicidade e Religião Civil, Coimbra, 2006. No prefácio escrevi então: "Pelo seu rigor, abrangência, poder de análise dos conceitos e de síntese, esta obra de Fernando Catroga fica como marco. Sobre a problemática tão complexa como urgente 
6. É neste quadro também que se insere a necessidade da presença do estudo do facto religioso nas escolas públicas. Para superar a ignorância mútua também a irracionalidade e o fundamentalismo.

Quantos cristãos saberão, por exemplo, que, se Adão e Eva fossem figuras reais e nossos contemporâneos, precisariam, para viajar para o estrangeiro, de um passaporte iraquiano? Quantos se lembram de que Abraão, que está na base das três religiões monoteístas - judaísmo, cristianismo, islão -, possuiria igualmente nacionalidade iraquiana? Quantos se lembram de que os primeiros capítulos do Génesis, referentes ao mito da criação e da queda, se passam na Mesopotâmia, onde mergulham algumas das nossas raízes culturais? Há guerras em curso, também por causa da divisão entre xiitas, sunitas e jihadistas. Mas quem conhece essas divisões e a sua origem e importância históricas? Qual é a relação entre religião e violência, religião e política, religião e desenvolvimento económico?

Há já alguns anos, Umberto Eco, agnóstico, lamentava-se: "Nas escolas italianas, Homero é obrigatório, César é obrigatório, Pitágoras é obrigatório, só Deus é facultativo. Se o ensino religioso se identificar com o do catecismo católico, no espírito da Constituição italiana deve ser facultativo. Só lamento que não exista um ensino da história das religiões. Um jovem termina os seus estudos e sabe quem era Poséidon e Vulcano, mas tem ideias confusas acerca do Espírito Santo, pensando que Maomé é o deus dos muçulmanos e que os quacres são personagens de Walt Disney..." 55

Ernst Bloch, o filósofo marxista heterodoxo e ateu religioso sublinhou que o desconhecimento da Bíblia constitui uma "situação insustentável”, pois produz bárbaros, que, por exemplo, perante a "Paixão segundo São Mateus", de Bach, ficam como bois a olhar para palácios. Sem a Bíblia, "não se pode compreender o gótico, a Idade Média, Dante, Rembrandt, Händel, Bach (...) nem a Missa solemnis de Beethoven, um Requiem, nada" ${ }_{56}$.

É um facto que não é possível ensinar literatura, história, filosofia, artes, sem uma cultura religiosa mínima. Por outro lado, vivemos num mundo cada vez mais multicultural e multi-religioso. Sem paz entre as religiões, não haverá paz no mundo. A paz exige o diálogo inter-religioso, mas o diálogo pressupõe o conhecimento das religiões.

da secularização, religião civil, laicidade, é mesmo o melhor que se escreveu em português" (p. 11).

${ }^{55}$ Umberto Eco, "Los dioses del mundo laico", in: Diario 16, Novembro de 1985. Cit. in: Carlos Díaz, Manual de historia de las religiones, Bilbao, 2. ed., 1998, pp. 587-588.

${ }^{56}$ Ernst Bloch, Antike Philosophie. Leipziger Vorlesungen zur Geschichte der Philosophie. Band 1, Frankfurt/M., 1985, pp. 450-451. 
Neste quadro, em 2002, a pedido do ministro francês da Educação Nacional, o filósofo agnóstico Régis Debray apresentou o Relatório sobre "O ensino do facto religioso na escola laica". O ministro Jack Lang escreve no Prefácio: se "a escola autêntica e serenamente laica deve dar acesso à compreensão do mundo", as religiões enquanto "factos de civilização" e "elementos marcantes e, em larga medida, estruturantes da história da humanidade" têm de estar presentes, e os professores, sem privilegiarem esta ou aquela opção espiritual, devem dar o justo lugar ao seu conhecimento nas várias disciplinas escolares.

R. Debray sublinha que "a história das religiões não é a recolha das lembranças da infância da humanidade". Mesmo se as religiões não têm o monopólio do sentido, integram o universo simbólico, como o direito, a moral, a história da arte ou o mito, sendo dever da escola aprofundar a sua inteligência reflexiva e crítica. Este esforço impõe-se tanto mais quanto o paradigma da economia, da gestão e das novas tecnologias não pode constituir "o horizonte único e último". É preciso reconhecer também que relegar o facto religioso para fora dos circuitos da transmissão racional, portanto, escolar, não é o melhor remédio para enfrentar "a vaga esotérica e irracionalista" bem como o fundamentalismo.

Uma vez que se trata da escola laica, deve tornar-se claro que "o ensino do religioso não é um ensino religioso". Por outras palavras, não se pode confundir informação histórica e crítica e catequese. Aqui, não se faz catecismo, pois o objectivo é uma "aproximação descritiva, factual e nocional das religiões em presença, na sua pluralidade, sem privilegiar nenhuma". De qualquer forma, a perspectiva "objectivante" não colide com a perspectiva "confessante", desde que as duas possam "existir e prosperar simultaneamente". São duas ópticas não concorrentes: a da fé e a da cultura.

É a laicidade que torna possível a coexistência das várias opções espirituais. Mas "a faculdade de aceder à globalidade da experiência humana, inerente a todos os indivíduos dotados de razão, implica a luta contra o analfabetismo religioso e o estudo dos sistemas de crenças existentes", sendo preciso passar de "uma laicidade de incompetência" - a religião não nos diria respeito - a uma "laicidade de inteligência" - é nosso dever compreendê-la ${ }^{57}$.

O princípio a manter no ensino do facto religioso na escola pública foi formulado pelo filósofo Hegel: não se trata de tornar os crentes descrentes nem os descrentes crentes, mas contribuir para que todos se tornem lúcidos.

${ }^{57}$ Régis Debray, L'enseignement du fait religieux dans l'école laique, Paris 2002, pp. $9-60$. 
7. Dentro da problemática do diálogo interreligioso propriamente dito, mas pressupondo os pontos anteriores, é fundamental passar pelos principais modelos da teologia das religiões: exclusivismo, inclusivismo e pluralismo.

O exclusivismo sustenta que há uma só religião verdadeira, a única depositária da revelação autêntica de Deus e, por isso, detentora exclusiva da verdade. As outras religiões, não possuindo a revelação sobrenatural de Deus, são consideradas falsas ou simplesmente naturais. Nelas, não se encontra a salvação.

Esta é a concepção que, de uma forma ou outra, tem estado presente em todas as religiões históricas. Na perspectiva católica, por exemplo, lembre-se o famoso princípio: "extra ecclesiam nulla salus" 58 (fora da Igreja - que é, evidentemente, a Igreja católica - não há salvação).

O inclusivismo também afirma que, em última análise, só há uma religião verdadeira, detentora da Verdade e da Salvação. No entanto, reconhece que as outras religiões participam dessa Verdade e Salvação. Têm elementos dessa Verdade e Salvação, mas, de qualquer forma, sempre de modo imperfeito e inacabado, pois a plenitude dos meios de salvação reside apenas na única religião verdadeira. Estão, dessa maneira, incluídas nela.

Neste contexto e dando mais uma vez o exemplo da Igreja católica, afirma-se que a plenitude da salvação de Deus por intermédio de Jesus Cristo reside na Igreja católica, embora os não cristãos também se possam salvar. Participam da salvação trazida por Cristo "de um modo só de Deus conhecido", "apesar da" sua religião e não "através dela".

O pluralismo, no sentido de uma teologia do pluralismo religioso, afirma não só a pluralidade de religiões, mas que essa pluralidade é salvífica, isto é, todas as religiões participam de modo autêntico da salvação de Deus. Assim, nenhuma delas ocupa o centro, que é ocupado só por Deus, de tal modo que todas são revelação de Deus e caminho para Deus. Todas as religiões estão referidas ao único centro, que é o Mistério de Deus.

No quadro do cristianismo, esta posição é muito recente e não bem aceite pelo Magistério ${ }^{59}$. De qualquer modo, ela supera tanto o exclusivismo como o inclusivismo, que se exprimiam também por outras categorias, respectivamente, o eclesiocentrismo e o cristocentrismo. $\mathrm{O}$ exclusivismo radicava precisamente no eclesiocentrismo, isto é, na afirmação de que na Igreja se encontra de modo

${ }^{58}$ Dz. 802: "Una vero est fidelium universalis Ecclesia, extra quam nullus ominino salvatur". Ver também Dz. 870 e 1351.

${ }_{59}$ Ainda recentemente foi condenada pela Congregação para a Doutrina da Fé a obra de J. M. Vigil, Teología del pluralismo religioso, Córdoba 2005. 
exclusivo a salvação de Deus. O cristocentrismo era a base do inclusivismo, no sentido de que os elementos de verdade e salvação presentes nas religiões não cristãs remetem para Cristo, único salvador.

8. O autêntico diálogo inter-religioso só pode dar-se no quadro do pluralismo, e, sintetizando, ele assenta em quatro pilares fundamentais.

8.1. Primeiro pilar: todas as religiões, desde que não só não se oponham ao Humanum, mas, pelo contrário, o afirmem e promovam, são reveladas e verdadeiras.

Como ficou dito, a revelação tem de entender-se no sentido, já explicado, de "maiêutica histórica". Aliás, todas as religiões se consideram, com razão, reveladas. Sem essa revelação, isto é, sem a manifestação de encontro do Mistério com o Homem e do Homem com o Mistério - se se quiser, depois da explicação já dada, Mistério a que, nas religiões monoteístas, se dá o nome de Deus -, como poderiam nascer as religiões?

Desde sempre Deus procura manifestar-se e comunicar-se a todos os seres humanos, a todos os povos. Assim, em todas as religiões há presença de revelação e, portanto, de verdade e santidade. Precisamente porque todas são reveladas, todas são também simultaneamente verdadeiras e falsas. Então, como escreveu Andrés Torres Queiruga, se há "verdade e santidade" nas religiões, "isso significa directa e imediatamente que os homens e as mulheres que as praticam se salvam nelas e por elas, e não a simples título individual nem, ainda menos, à margem nem apesar delas". Deus "está a revelar-se e a exercer a sua salvação em todas e cada uma das religiões, sem que alguma vez algum homem ou mulher tenham estado privados da oferta da sua presença amorosa"60.

8.2. Segundo pilar: as religiões são manifestações e encarnações da relação de Deus com o Homem e do Homem com Deus. Todas são relativas, no duplo sentido de relativo, que é dito já no próprio étimo latino: o verbo irregular refero, donde vem referir, referência, retuli, relatum, donde provém relativo e relação. Elas são relativas, na medida em que, uma vez que não caem do céu, estão inevitavelmente inseridas num determinado contexto histórico-social. Elas são relativas num segundo sentido: estão referidas, isto é, em relação com o Absoluto, mas elas próprias não são o Absoluto.

O Absoluto não pode ser possuído ou dominado pelo Homem. Não se pode esquecer a dupla afirmação do Evangelho em relação a Jesus. Por um lado, Jesus diz: "Eu e o Pai somos um, quem me vê a mim vê o Pai”", mas, por outro, afirma:

${ }^{60}$ Andrés Torres Queiruga, Do terror de Isaac ó Abbá de Xesús, Estella 1999, p. 228. 
“O Pai é maior do que eu". Quando o Homem fala de Deus, está sempre a falar do Deus dito por ele e não, embora referido a ele, do Deus em si mesmo.

Como disse A. Peteiro Freire, "não podemos pretender que uma religião tenha a verdade totalmente nem encerrar Deus numa determinada religião. Temos de 'deixar Deus ser Deus', por cima das nossas categorias e definições. Porque na medida em que renunciarmos a possuí-lo, encontrá-lo-emos como Deus verdadeiro. O verdadeiro Deus nunca é 'à nossa medida'. Ninguém possui a verdade completa. Só Deus"61 . O Cardeal Carlo Martini também disse: "Não podes fazer Deus católico. Deus está para lá das fronteiras e delimitações que construímos. Ele não se deixa dominar nem domesticar"62.

O místico budista Nagarjuna foi radical. Segundo ele, o Homem, a caminho da verdade suprema, religioso-mística, não pode ficar na dialéctica comum, tendo mesmo de ir além da dialéctica hegeliana (ser, não ser e devir), para atingir a dialéctica que nega as quatro possibilidades - afirmação (é), negação (não é), afirmação e negação (é e não é), dupla negação (nem é nem não é). No termo, é o Silêncio ${ }^{63}$.

Segue-se daqui que o que se chamou missão, no sentido de converter outro a uma religião, tem de ser repensada. Já não se trata, de facto, por exemplo, de o cristão converter o budista ao cristianismo ou o budista converter o cristão ao budismo, mas de ambos se converterem ao Mistério que os envolve aos dois, o que, paradoxalmente, fará com que o cristão se tornará mais e menos cristão e o budista mais e menos budista. De facto, nessa conversão ao Mistério, serão obrigados a criticar tudo o que de negativo existe na religião de cada um e a aprofundar e viver o melhor.

É assim que o jesuíta Juan Masiá, em diálogo com o budista Kotaró Suzuki mostra que "é necessário reinterpretar a noção de missão: viver a missão como encontro e caminho em vez de como indoutrinação, proselitismo e colonização. Além disso, não me cansarei de repetir uma e outra vez que é preciso colocar o desafio de uma nova missão: a que levam a cabo as religiões juntas para ajudar o mundo a despertar para a sua humanidade e para a religiosidade ou espiritualidade. (...) Também é necessário reinterpretar a noção de conversão. Não é minha missão converter o budista ao cristianismo, mas ajudarmo-nos mutuamente a convertermo-nos ambos ao Mistério que nos transcende: "X" - designemos assim o Mistério da Origem amorosa da Vida - está para

\footnotetext{
${ }^{61}$ Mons. A. Peteiro Freire in: Vida Nueva 2308 (Dezembro de 2001) p. 50.

${ }^{62}$ Kardinal Carlo M. Martini/Georg Sporschill, Jerusalemer Nachtgespräche, Friburgo, Basileia, Viena, 2008, p. 26.

${ }^{63} \mathrm{Cf}$. Hans Küng, El cristianismo y las grandes religiones, pp. 456-457.
} 
lá da imagem que ambos temos de Buda e de Deus. (...) Como resultado dos encontros interculturais e inter-religiosos, ambas as partes saem com mais e menos identidade cultural, mais e menos crentes que antes. Por exemplo, o budista sai mais e melhor - ou, noutro sentido, menos - budista que antes, e o cristão mais e melhor - ou, noutro sentido, menos - cristão que antes" ${ }^{64}$.

8.3. Assim, o segundo pilar exige o terceiro: se as religiões não são o Absoluto, embora referidas a ele - deste modo se supera o relativismo, pois aqui do que se trata é de perspectivismo: as diferentes religiões são perspectivas sobre e vivências do Absoluto; as religiões também não são todas iguais, pois, como escreve Andrés Torres Queiruga, deve-se falar de "universalismo assimétrico", já que "é impossível ignorar o facto das diferenças reais nos êxitos das diferentes religiões: não porque Deus discrimine, mas porque por parte do homem a desigualdade acaba por ser inevitáve ${ }^{65}$-, os homens e as mulheres religiosos devem dialogar para melhor se aproximarem do Mistério divino absoluto já presente em cada religião, mas sempre transcendente a cada uma e a todas.

Não se trata, portanto, de mera tolerância, que supõe ainda uma superioridade de quem tolera o outro considerado inferior. É o próprio Mistério infinito de Deus que exige o diálogo para que os crentes se enriqueçam mutuamente sempre a caminho do Mistério que se revela e ao mesmo tempo se oculta, e do qual o ser humano não pode apoderar-se nem dominar. Como escreveu Edward Schillebeeckx, "podemos e devemos dizer que há mais verdade (religiosa) em todas as religiões juntas do que numa só, e isto é válido também para o cristianismo" 66

Precisamente porque nenhuma religião nem todas juntas possui o Mistério na sua ultimidade e porque são ao mesmo tempo verdadeiras e imperfeitas, podem e devem aprender umas das outras e complementar-se. Como escreveu P. Knitter, a título de exemplo e concretizando este aspecto, "a doutrina cristã da Trindade precisa do acento islâmico no monoteísmo; o vazio impessoal do budismo precisa da experiência cristã do Tu divino; o ensinamento cristão sobre a distinção entre o absoluto e o finito precisa da visão hindu sobre a não dualidade de Brahman e atman; o conteúdo profético-prático da tradição judaico-cristã precisa da tradição do Oriente que acentua a contemplação pessoal e a acção sem perseguir a eficácia. 'Estas polaridades contrastantes não se anulam

\footnotetext{
${ }^{64}$ Juan Masiá y Kotaró Suzuki, El Dharma y el Espíritu, Madrid, 2007, p. 146.

${ }^{65}$ Andrés Torres Queiruga, Diálogo de las religiones, pp. 74-75.

${ }^{66}$ Edward Schillebeeckx, Menschen. Die Geschichte von Gott, Friburgo, Basileia, Viena, 1990 , p. 214.
} 
umas às outras, como o dia não suprime a noite nem a noite o dia. É por isso que as religiões devem dar testemunho umas às outras, na sua diversidade, pois só assim podem alcançar o seu sentido pleno" "67. Neste contexto, deve evitar-se falar em "eleição" e "povo eleito".

Ainda neste contexto, Andrés Torres Queiruga apresenta o conceito de "inreligionação", para significar o enriquecimento mútuo das diferentes religiões: “como na ‘inculturação’ uma cultura assume riquezas doutras sem renunciar a ser ela mesma, algo semelhante sucede no plano religioso" ${ }^{6}$, primando de tal modo entre as grandes religiões "a simbiose e o enriquecimento" que em certos casos excepcionais há pessoas que se sentem "pertencendo identicamente a duas religiões: tal é o caso dos que, como Raimon Panikkar ou Henri le Saux, se consideram a si mesmos hindus-cristãos" 69 .

8.4. Por paradoxal que pareça, o quarto pilar afirma que do diálogo inter-religioso fazem parte também os ateus, pois o que, antes de mais, nos vincula a todos é a humanidade, concluindo-se, assim, que os ateus são aqueles que, por estarem "de fora", talvez melhor possam aperceber-se da inumanidade, superstição e idolatria, que tantas vezes afectam as religiões históricas.

Se Deus é o Mistério que tudo penetra e a todos envolve, o respeito pelos outros crente, pelos outros homens e mulheres, por todas as criaturas, não é algo acrescentado à fé religiosa, mas exigido pelo próprio dinamismo dessa fé. Acreditar em Deus implica em si mesmo acreditar no ser humano, em todo o ser humano. Pelo menos, segundo o cristianismo, Deus criou e cria continuamente, revelou-se e revela-se por causa do interesse do ser humano. O seu interesse não é ele mesmo. Como disse Santo Ireneu, "Gloria Dei homo vivens", a glória de Deus é o Homem vivo, no sentido de plenamente realizado, que vai tão longe quanto possível na realização harmónica de todas as sua possibilidades ${ }^{70}$.

${ }^{67}$ Paul Knitter, Ein Gott-viele Religionen. Gegen den Absolutheitsanspruch des Christentums, Munique, 1988, p. 179. A citação é de Henri Maurier, "The Christian Theology of the Non-Christian Religions, in: Lumen Vitae 21 (1976) 72.

${ }^{68}$ Andrés Torres Queiruga, Do terror, pp. 236-237.

${ }^{69}$ Id., o. c., p. 238.

70 Juan Masiá, no âmbito da sua experiência de encontros inter-religiosos, resumiu em cinco pontos o quadro em que a sua prática se deve desenrolar, no que é acompanhado pelo seu interlocutor budista Kotaró Suzuki: "1. Antes de mais, começar por nos conhecermos mutuamente e pôr sobre a mesa elementos comuns. 2. A seguir, na base de partilhar não só conversa e mesa, mas também vida e acção social, crescer em confiança para pôr sobre a mesa as diferenças: o que não temos em comum e inclusive nos parece, por vezes, incompatível. 3. Em terceiro lugar, que cada religião faça autocrítica publicamente, reconhecendo o lastro da história que transportamos, uma trajectória com riquezas e penúrias, em que por vezes atraiçoámos a tradição fundacional de cada religião. 4. Em quarto lugar, com base nos três passos anteriores, que não se 
A causa de Deus é, pois, a causa do Homem. Por isso, a ortopraxis tem prevalência sobre a ortodoxia. Isso foi visto nomeadamente por Gotthold Ephraim Lessing na sua obra clássica Nathan, o Sábio, que apareceu em 1779, sendo representada pela primeira em Berlim em 1783 e que constitui "um dos textos determinantes de toda a história espiritual e cultural que deu origem à ideia europeia de tolerância" ${ }^{171}$. Confrontado com a questão dos três anéis, símbolo das três religiões monoteístas, não é capaz de decidir qual é o verdadeiro, dizendo aos filhos que acabem, portanto, com todo o conflito, pois o pai ama de igual modo os três. Decisivo é que mostrem a verdade da fé mediante as boas obras e o moror $^{72}$. Critério essencial da verdade de uma religião é o seu compromisso com os direitos humanos e a realização plena do Homem.

dão num dia nem num mês, começar a construir um horizonte comum de linguagem e diálogo, não para elaborar forçada e sincreticamente uma espécie de esperanto das religiões, mas para nos deixarmos mutuamente transformar, 5. Finalmente, todo este processo ficaria incompleto, se não partilhasse a fundo o elemento que podemos chamar, se se não interpretar mal a palavra, mistério ou místico. Não partilhar apenas a mesa, a acção e o diálogo, mas o silêncio: poder estar em comunhão no silêncio contemplativo, para que o mistério que penetra, envolve e transcende todas as religiões nos conduza a uma espiritualidade, que está para lá delas todas”. Juan Masiá y Kotaró Suzuki, o. c., pp. 99-100.

${ }^{71}$ Heinrich Schmidinger (Hrsg.), Wege zur Toleranz. Geschichte einer europäischen Idee in Quellen, Darmstadt, 2002, p. 283.

${ }^{72}$ G. E. Lessing, Nathan der Weise. Ein dramatisches Gedicht in fünf Aufzügen, Husum/ /Nordsee, s. d., pp. 64-68. 